\title{
The Problems Faced by Senior High School Students in Reading Narrative Text
}

\section{Masalah yang Dihadapi Siswa Sekolah Menengah Atas dalam Memahami Teks Naratif dalam Bahasa Inggris}

\author{
Mochamad Khalif Rizqon, Sri Andreani*, Utari Praba Astuti \\ Universitas Negeri Malang, Jl. Semarang No. 5 Malang, Jawa Timur, Indonesia \\ *Penulis korespondensi, Surel: sri.andreani.fs@um.ac.id
}

Paper received: 27-09-2021; revised: 31-10-2021; accepted: 21-11-2021

\begin{abstract}
Reading comprehension is an essential skill that students need to master. It helps students to develop their knowledge, skill, and memory to prepare for real life challenges. However, students in Indonesia still experience reading comprehension problems. Both PISA and the National Reading Index show that Indonesian students' literacy in Indonesian text is low. Previous research also indicate that most Indonesian students do not understand English texts especially narrative text. This study aimed to identify what problems the senior high school students faced in reading English texts and how many percent of them faced reading comprehension problems. The design of the study was a survey. The findings of this research reveal that $52 \%$ of the students had problems in vocabulary and $43.2 \%$ of the students had problems in background knowledge when reading English texts. Therefore, the students need to exercise more on their vocabulary and background knowledge skills by reading more narrative text.
\end{abstract}

Keywords: reading comprehension problems, survey, narrative text

\begin{abstract}
Abstrak
Pemahaman membaca adalah keterampilan penting yang harus dikuasai oleh siswa. Ketrampilan tersebut dapat membantu siswa untuk mengembangkan pengetahuan, keterampilan, dan memori mereka untuk menghadapi tantangan di kehidupan nyata. Namun, siswa di Indonesia masih mengalami masalah dalam memahami bacaan. Survey dari PISA dan Indeks Literasi Nasional menunjukkan bahwa literasi siswa Indonesia dalam teks bahasa Indonesia masih rendah. Penelitian sebelumnya juga menunjukkan bahwa sebagian besar siswa Indonesia tidak memahami teks bahasa Inggris terutama teks naratif. Penelitian ini bertujuan untuk mengidentifikasi masalah apa yang dihadapi siswa sekolah menengah atas dalam membaca teks bahasa Inggris dan berapa persen dari mereka yang masih ada masalah di pemahaman bacaan. Desain penelitian ini adalah survei. Temuan penelitian ini mengungkapkan bahwa 52\% siswa memiliki masalah dalam kosakata dan 43,2\% siswa memiliki masalah dalam pengetahuan latar belakang saat membaca teks bahasa Inggris. Oleh karena itu, siswa perlu lebih banyak melatih kosakata dan keterampilan pengetahuan latar belakang mereka dengan membaca lebih banyak teks naratif.
\end{abstract}

Kata kunci: permasalahan dalam memahami bacaan, survei, teks naratif

\section{Introduction}

Reading comprehension is one of the skills that must be mastered in a foreign language, including English. According to Snow (2010), reading comprehension is a process of extracting the meaning of the written text. Cordeur (2010) explains that reading comprehension is the skill to remember some important details of the text and drawing the conclusion based on those details. In other words, reading comprehension is the ability to understanding a text and draw a conclusion based on it. Reading comprehension has been integrated into learning in 
Indonesian schools. Reading comprehension helps to construct a world view and disciplinespecific literacy practices. Therefore, it is clear that more attention to comprehension is needed across the grades (Snow, 2010). In other words, reading comprehension help the students to develop their knowledge, skill, and memory to prepare them for the real-life challenges in society such as decision making and cooperating with other people.

However, Indonesian students' reading level is still low. The national reading index of 2019 (Solihin, Utama, Pratiwi, \& Novirina, 2019) states that the Indonesian students' reading literacy level on Indonesian text is categorized as low literacy level. The national reading Index was conducted by the Indonesian Ministry of Education to measure the literacy level of Indonesian students. Then, the PISA 2018 score for Indonesia in reading is 371 (OECD, 2018). This score is considered below average because the average score in PISA 2018 is 453. PISA is an international survey to measure 15 years olds' ability to use their reading, mathematics, and science knowledge. Both the national reading index and PISA used Indonesian text as the reading material. The reading level in Indonesian turned out to be the same. According to Dahliana (2016), although Indonesian students already learned English, most of them still does not understand various English texts. According to Jayanti (2016), EFL students still have some difficulties in reading English text. The difficulties are in the vocabulary, syntactic and semantic analysis of the text. From all these research results, we can see that Indonesian students still have problems with reading comprehension.

Previous research shows that students experienced problems, such as insufficient knowledge in vocabulary, background knowledge, and grammar (Davoudi \& Yousefi, 2015). Then there are problems in text structure and language features. The first problem is vocabulary. Vocabulary and reading comprehension are strongly correlated. Nanda and Azmy (2020) also explain that Indonesian EFL students have poor reading comprehension performance due to the lack of vocabulary, prior knowledge and motivation. In addition, Stæhr (2008) studied 88 Danish students' reading comprehension skills and found a strong correlation between vocabulary size and reading comprehension. Vocabulary mastery contributes to successful reading comprehension. When students have many vocabularies, then, it will be easy for them to comprehend a text. According to Masrai (2019), vocabulary plays important role in improving the students' reading comprehension. The second problem is background knowledge. Background knowledge is affecting the students' reading comprehension (Elbro \& Buch-Iversen, 2013). Background knowledge is often underaddressed by the teacher (Smith, 2021). Hamra and Syatriana (2010) also state that teachers should focus on exercising the student's prior knowledge and reading strategies to improve reading comprehension. Background knowledge plays a vital role in students' reading comprehension. To comprehend English text, students are required to draw inferences that rely on having rich prior knowledge (Neuman, Kaefer, \& Pinkham, 2014). Students might not be able to comprehend the text if they do not have enough background knowledge to comprehend the text. Then, the third problem is grammatical knowledge. Basic grammatical knowledge also plays an essential role because it shows the time signature in the text passage. Time signature helps the students to determine the flow of the text. In addition, people who speak the same language can communicate because they intuitively know the grammar system of that language (Subasini \& Kokilavani, 2013). The previous statement is also true for the readers. When readers intuitively know the grammar of the language, they should be able to comprehend a text correctly. Andini Hadriana, and Delfi (2017) state that there is a high correlation between grammar mastery and reading comprehension. This research indicates 
that grammar mastery is important in reading comprehension. The fourth problem is text structure. The previous research result from Khoirunnisa (2019) shows that there is a text structure problem in students' reading comprehension. The text structure is important for students because it helps the students to make connections from one paragraph to another paragraph. It also helps the students to identify the section of the text. The last problem is language features. Gunning (2002) divide the reading comprehension problems into language features problems, background knowledge problems, and motivation problems. Language features help students to identify the dialogue that happened in the text whether it is a direct speech or indirect speech. Language features is also similar with grammar in identifying the time flow of the text. Based on the explanation above, the researcher focused on these five problems.

The reading material is a narrative text. Narrative text is a fictional or imaginative story, and it is usually presented in a chronologically series of events that happened or experienced by the characters in a text. Furthermore, the narrative text emphasizes the understanding of plot, theme, characters, and events, and how they relate to each other. The narrative texts have been a problems for students in previous research. As the students' progress to a higher grade, they might have difficulties understanding narrative texts (Dymock, 2007). A previous research result from Sari, Santihastuti, and Wahjuningsih (2020) show that the students still has difficulty when understanding the vocabulary in narrative text. Research result from Andri, Supardi, and Suhartono (2015) show that the students have difficulties in identifying the generic structure of narrative text. Amalia (2017) reports that the students in Junior High School Tanjung Batu have difficulties in comprehending the narrative text. Then, students still lack of vocabulary to understand a narrative text (Amalia, 2017). Then, the researcher chooses narrative texts because it is suitable reading material that covers five problems mentioned before. The previous research showed the students still have problems with narrative text. Therefore, the researcher interested in surveying the reading comprehension problems in narrative text.

Based on the previous findings, the researcher would like to do the same survey but with the different subject. In this case the subject is $11^{\text {th }}$ grade senior high school students in Ponorogo. The examination on the students in Ponorogo has not been done before. And then, the indication from the previous survey showed that the Indonesian students have problems in reading narrative text. There are five reading comprehension problems that might occur on the students. Therefore, the researcher would like to survey the students in Ponorogo to check whether the students have those problems or not.

The researcher formulated the research problem into: "What problems did the senior high school students experience in reading a narrative text?"

The significance of this study is to identify the students' problems in reading narrative text. This study was intended to help the teachers and future researchers in identifying the students' problems in reading narrative text. By knowing the problems that have been identified in this study, the teacher can increase their awareness about the students' problems in reading narrative text. Then, the teacher can focus more on which reading aspects that the student needs to improve. Also, the teacher can anticipate their students' mistakes during reading comprehension activities and improve them later. Also, future researchers can use this study's result as a reference in researching the Indonesian students' reading comprehension 
skills. Future researchers can develop techniques or media to improve the Indonesian students' reading comprehension skills in the future.

\section{Methods}

The design of this study was survey research. Survey typically gathers data at a particular point of time to describe the nature of existing conditions by gathering opinions, attitudes, preferences, and perceptions of the researcher's people of interest (Cohen,Manion, \& Morrison, 2007). This research was aimed to investigate the possible cause of reading comprehension problems during their narrative text reading activity.

The researcher used a questionnaire for collecting data from participants. The researcher chose this instrument to address various reading comprehension problems from senior high school students. Questionnaire is also suitable for senior high school students' current English capabilities and is easy to answer. Then, the researcher developed the questions based on the reading problems on previous research in the EFL classroom. The problems are vocabulary, text structure, language features, background knowledge, and grammar.

The researcher developed a questionnaire's blueprint first so that the questionnaire is relevant and unbiased. It is crucial to develop the questionnaire in the best possible way to get unbiased responses (Latief, 2017). The researcher developed the questions as clear as possible and make sure the sentences are clear for the respondents. Then, the researcher gave the questionnaire to the English teacher of SMAN 2 Ponorogo for the feedback. The feedback from the teacher was mainly about adding more questions about giving some examples, so the students will stay focus and not answering the questions halfheartedly.

The researcher distributed the questionnaire on November 26th, 2020, until January 1st, 2021, through an online link. The researcher distributes the questionnaire with the teachers' help to reach all the samples within different schools. Then, on January 2nd, 2021, all of the 227 responses were gathered.

For the research data, the subjects were the eleventh-grade students of senior high schools in Ponorogo. The researcher chose eleventh-grade students because they had learned the narrative texts twice. The eleventh-grade students should have more experience in narrative text, so surveying the eleventh-grade students is relevant. There are two data which are population and sample.

The first data is the population. The population of the research was the eleventh graders of both state and private senior high schools in Ponorogo. There are three state senior high schools in Ponorogo and four private senior high schools in Ponorogo. According to the Indonesian Ministry of Education database, there are 1529 eleventh graders of senior high schools in Ponorogo (Dapo Kemendikbud, 2020). The database also shows that the number of eleventh graders ranged from 15 students (SMAS Hudaya) to 408 students (SMAN 1) (Dapo Kemendikbud, 2020).

The next data is the sample. The researcher chose to use sample because of the lack of time, finances, and accessibility needed when surveying the whole population. In this study, to ensure that the sample represents the whole population, the sample is drawn randomly using a simple random sampling technique. Then, the researcher determined the size of the sample. 
The researcher used the sample calculator from the Creative Survey System website. The website calculates the sample size by inputting the population number, desired confidence level, and margin error. After that, the researcher began to input the population, which was 1529 , and a 95 percent confidence level with a 6 percent margin of error, and the result was 227. Thus in this study, the researcher gathered the data from 227 participants. The participants were chosen randomly from public and private senior high schools. The detail of the sample is in table 1.

Table 1. Sample and Population

\begin{tabular}{clcc}
\hline No & \multicolumn{1}{c}{ School } & Population & Sample \\
\hline 1 & SMA 1 Ponorogo & 408 & 67 \\
2 & SMA 2 Ponorogo & 343 & 48 \\
3 & SMA 3 Ponorogo & 356 & 30 \\
4 & SMA Muhammadiyah & 208 & 32 \\
5 & SMA Bakti & 130 & 15 \\
6 & SMA Merdeka & 69 & 14 \\
7 & SMA Hudaya & 15 & 5 \\
\hline & Total & 1529 & 227 \\
\hline
\end{tabular}

For the first data analysis, the researcher analyzed what are the proportion of the students' answer on each question. To be able to do that, the researcher determined the students' percentage on each answer in a particular question or statement. To find the students' percentage on each answer in the questions or statements, the researcher used the following formula.

$$
p=\frac{x}{n} \times 100 \%
$$

Notes:

$p$ : The Students' percentage on each answer

$x$ : The number of sample who choose a specific answer

$n$ : The total sample

For the second data analysis, the researcher determined the students' average percentages on the specific reading comprehension problem. The researcher calculated the students' average percentages based on total of the students' percentages on the selected answer within the specific reading comprehension problem. For example, there are three questions in the vocabulary problem and all of the students chose to answer the agree option. Then, the total of the students' percentages on the agree answer will be $300 \%$. After that, the researcher divide that $300 \%$ with the number of questions which is 3 . Then, the students' average percentage of the vocabulary problem on the agree answer is $100 \%$. In addition, the answers in the questionnaire consist of strongly disagree, disagree, agree, and strongly agree. To simplify the average results, the researcher grouped those four answers into two groups. The average results from the disagree and strongly disagree were combined into "disagree" and the results from agree and strongly agree were combined into "agree." The disagree option means that the students have the problem, while the agree option means that the students do not have the problem. From the average percentage results, we can see which reading comprehension problems have a high percentage on the students. The following is the formula 
that determined the students average percentage of the particular reading comprehension problem.

$$
\bar{x}=\frac{\sum x}{n}
$$

Notes:

$\bar{x}:$ The students' average percentage of a reading comprehension problem

$x$ : The students' percentages on a selected answer in a particular reading comprehension problems

$n:$ The number of questions in a particular reading comprehension problems

Using that formula, the researcher could see the average percentage of the specific reading comprehension' problems that occurs on the students.

For the last data analysis, the researcher determined the students' overall score. To find the students' overall score, the researcher calculated the mean of all the five previous average percentage results. The purpose is to know the overall result of the students' reading comprehension ability, whether they still have the difficulties or not. Similar to the students' average percentage results, the overall score were group into two which are disagree and agree. The disagree option means that the students have the problem, while the agree option means that the students do not have the problem. The following is the formula that determined the students' overall score.

$$
\bar{x}=\frac{\sum x}{n}
$$

Notes:

$\bar{x}:$ The overall score

$x:$ The students' average percentage of every reading comprehension problems

$n$ : The total number of reading comprehension problems

\section{Findings and Discussion}

The researcher found few students experienced one or more reading comprehension problems when they read narrative text. The aspects that have percentage of problems for students are vocabulary and background knowledge. The details of each problem will be explained in the following sections.

\subsection{Findings}

The first findings is on the students' vocabulary problems. There are three statements in the questionnaire. The details of the results are presented in Table 2. In the first statement, only $68(30 \%)$ out of 227 students know most of the vocabulary in narrative text. This result confirms the previous research result, which states that the students think that narrative text is difficult because of its vocabularies (Sari et al., 2020). They also state that narrative text tends to use difficult vocabularies, so they do not understand its meaning. For the next statements, only 100 (44\%) students can identify the vocabularies in narrative text. However, around 158 $(69,5)$ students say that they can identify the meaning of some vocabularies by elaborate them with previous sentences. The students tend to use that technique when looking for the meaning of difficult vocabularies. In the end, the average percentage for vocabulary problems are, $52.3 \%$ of students still have the vocabulary problems and $47.8 \%$ of students do not have the vocabulary problems. As we can see from the on the average percentage, the students still have 
difficulties identifying vocabularies when they conduct reading comprehension in narrative text. The students need more exercise in identifying the meaning of most vocabularies in narrative text.

Table 2. The Students' Vocabulary Problems

\begin{tabular}{|c|c|c|c|c|c|}
\hline No & Questions/Statements & $\begin{array}{l}\text { Strongly } \\
\text { Disagree }\end{array}$ & Disagree & Agree & $\begin{array}{c}\text { Strongly } \\
\text { Agree }\end{array}$ \\
\hline 1 & $\begin{array}{l}\text { I know most of the } \\
\text { vocabularies in narrative text }\end{array}$ & $\begin{array}{c}33 \\
(14.5 \%)\end{array}$ & $\begin{array}{c}126 \\
(55.5 \%)\end{array}$ & $\begin{array}{c}50 \\
(22 \%)\end{array}$ & $\begin{array}{c}18 \\
(8 \%)\end{array}$ \\
\hline 2 & $\begin{array}{l}\text { Sometimes I can identify most } \\
\text { of the vocabularies in } \\
\text { narrative text easily. }\end{array}$ & $\begin{array}{c}12 \\
(5.3 \%)\end{array}$ & $\begin{array}{c}115 \\
(50.6 \%)\end{array}$ & $\begin{array}{c}80 \\
(35.2 \%)\end{array}$ & $\begin{array}{c}20 \\
(8.8 \%)\end{array}$ \\
\hline 3 & $\begin{array}{l}\text { When there are some difficult } \\
\text { vocabularies, I can look for the } \\
\text { meaning by looking at the } \\
\text { context }\end{array}$ & $\begin{array}{c}5 \\
(2.2 \%)\end{array}$ & $\begin{array}{c}64 \\
(28.2 \%)\end{array}$ & $\begin{array}{c}112 \\
(49.3 \%)\end{array}$ & $\begin{array}{c}46 \\
(20.2 \%)\end{array}$ \\
\hline & Average Results & $7.3 \%$ & $44.7 \%$ & $35.5 \%$ & $12.5 \%$ \\
\hline & Total & \multicolumn{2}{|c|}{$52 \%$} & \multicolumn{2}{|c|}{$48 \%$} \\
\hline
\end{tabular}

The second findings is the text structure problems. There are four statements regarding the students' problem in the text structure. The details of the result are presented in Table 3.

Table 3. The Students' Text Structure Problems

\begin{tabular}{|c|c|c|c|c|c|}
\hline No & Questions/Statements & $\begin{array}{l}\text { Strongly } \\
\text { Disagree }\end{array}$ & Disagree & Agree & $\begin{array}{c}\text { Strongly } \\
\text { Agree }\end{array}$ \\
\hline 1 & $\begin{array}{l}\text { I know the text structure of } \\
\text { narrative text }\end{array}$ & $\begin{array}{c}5 \\
(2.2 \%)\end{array}$ & $\begin{array}{c}33 \\
(14.5 \%)\end{array}$ & $\begin{array}{c}140 \\
(61.6 \%)\end{array}$ & $\begin{array}{c}49 \\
(21.5 \%)\end{array}$ \\
\hline 2 & $\begin{array}{l}\text { I think the text structure of } \\
\text { narrative text is easy }\end{array}$ & $\begin{array}{c}5 \\
(2.2 \%)\end{array}$ & $\begin{array}{c}25 \\
(11 \%)\end{array}$ & $\begin{array}{c}170 \\
(75 \%)\end{array}$ & $\begin{array}{c}27 \\
(12 \%)\end{array}$ \\
\hline 3 & $\begin{array}{l}\text { When I read a narrative text, I can } \\
\text { identify each text structure in the } \\
\text { narrative text }\end{array}$ & $\begin{array}{c}9 \\
(4 \%)\end{array}$ & $\begin{array}{c}34 \\
(15 \%)\end{array}$ & $\begin{array}{c}158 \\
(69.6 \%)\end{array}$ & $\begin{array}{c}26 \\
(11.4 \%)\end{array}$ \\
\hline 4 & $\begin{array}{l}\text { I understand the function of each } \\
\text { text structure in narrative }\end{array}$ & $\begin{array}{c}8 \\
(3.5 \%) \\
\end{array}$ & $\begin{array}{c}34 \\
(15 \%) \\
\end{array}$ & $\begin{array}{c}158 \\
(69.6 \%)\end{array}$ & $\begin{array}{c}27 \\
(11.9 \%) \\
\end{array}$ \\
\hline & Average Results & $3 \%$ & $14 \%$ & $68.9 \%$ & $14.1 \%$ \\
\hline & Total & \multicolumn{2}{|c|}{$17 \%$} & \multicolumn{2}{|c|}{$83 \%$} \\
\hline
\end{tabular}

The first result is that there are 189 (83\%) students already understand the text structure. And there are $38(16.7 \%)$ students who do not understand the text structure of narrative text. Those students are also able to write all the text structure of a narrative text. Also, they can write one of the functions of the text structure of a narrative text. The students can also write one of the text structure in narrative text and describe its function. Then, 197 (84\%) students understand the structure of narrative text. Next, 184 (81\%) students can identify the text structure when they read a narrative text. They also understand each function of the narrative text. Those students can also write one of the text structure in narrative text and describe its function. The average percentage for students' problems in the text structure is $16.8 \%$ states that they have the text structure problem and around $83 \%$ states that they do not have the text structure problem. All in all, the students have no significant problems with the text structure of a narrative text. 
The third findings is language features. There are seven statements in the language features problems. The details of the result are presented in Table 4.

Table 4. The Students' Problems in Language Features

\begin{tabular}{|c|c|c|c|c|c|}
\hline No & Questions/Statements & $\begin{array}{l}\text { Strongly } \\
\text { Disagree }\end{array}$ & Disagree & Agree & $\begin{array}{c}\text { Strongly } \\
\text { Agree }\end{array}$ \\
\hline 1 & $\begin{array}{l}\text { I know about the language } \\
\text { features of narrative text }\end{array}$ & $\begin{array}{c}6 \\
(2.6 \%)\end{array}$ & $\begin{array}{c}78 \\
(34.3 \%)\end{array}$ & $\begin{array}{c}113 \\
(49.7 \%)\end{array}$ & $\begin{array}{c}30 \\
(13.2 \%)\end{array}$ \\
\hline 2 & $\begin{array}{l}\text { One of the language features } \\
\text { of narrative text is many } \\
\text { usages of Verb } 2\end{array}$ & $\begin{array}{c}6 \\
(2.6 \%)\end{array}$ & $\begin{array}{c}17 \\
(7.5 \%)\end{array}$ & $\begin{array}{c}165 \\
(72.6 \%)\end{array}$ & $\begin{array}{c}39 \\
(17.2 \%)\end{array}$ \\
\hline 3 & $\begin{array}{l}\text { One of the language features } \\
\text { of narrative text is the use of } \\
\text { simple past tense }\end{array}$ & $\begin{array}{c}3 \\
(1.3 \%)\end{array}$ & $\begin{array}{c}25 \\
(11 \%)\end{array}$ & $\begin{array}{c}151 \\
(66.5 \%)\end{array}$ & $\begin{array}{c}48 \\
(21.1 \%)\end{array}$ \\
\hline 4 & $\begin{array}{l}\text { I am aware of the usage of the } \\
\text { adverb of time in narrative } \\
\text { text }\end{array}$ & $\begin{array}{c}16 \\
(7 \%)\end{array}$ & $\begin{array}{c}92 \\
(40.5 \%)\end{array}$ & $\begin{array}{c}91 \\
(40 \%)\end{array}$ & $\begin{array}{c}28 \\
(12.3 \%)\end{array}$ \\
\hline 5 & $\begin{array}{l}\text { I know the example of the } \\
\text { adverb of time in narrative } \\
\text { text. If you agree with that } \\
\text { statement, write one example } \\
\text { of the adverb of time. }\end{array}$ & $\begin{array}{c}15 \\
(6.6 \%)\end{array}$ & $\begin{array}{c}82 \\
(36 \%)\end{array}$ & $\begin{array}{c}100 \\
(44 \%)\end{array}$ & $\begin{array}{c}30 \\
(13.2 \%)\end{array}$ \\
\hline 6 & $\begin{array}{l}\text { I know that the narrative text } \\
\text { often used direct speech }\end{array}$ & $\begin{array}{c}3 \\
(1.3 \%)\end{array}$ & $\begin{array}{c}69 \\
(30.3 \%)\end{array}$ & $\begin{array}{c}121 \\
(53.3 \%)\end{array}$ & $\begin{array}{c}34 \\
(15 \%)\end{array}$ \\
\hline 7 & $\begin{array}{l}\text { I'm familiar with the example } \\
\text { of direct speech. }\end{array}$ & $\begin{array}{c}2 \\
(0.8 \%)\end{array}$ & $\begin{array}{c}72 \\
(31.7 \%)\end{array}$ & $\begin{array}{c}109 \\
(48 \%)\end{array}$ & $\begin{array}{c}44 \\
(19.3 \%)\end{array}$ \\
\hline & Average Results & $3 \%$ & $27 \%$ & $54 \%$ & $16 \%$ \\
\hline & Total & \multicolumn{2}{|c|}{$30 \%$} & \multicolumn{2}{|c|}{$70 \%$} \\
\hline
\end{tabular}

Based on Table 4, there are $143(62.9 \%)$ students that already know the language features of a narrative text. And then, there are 204 (90\%) students who already know that one of the language features in a narrative text is many second verb usage. There are many language features in narrative text, such as tenses, adverbs of time, and direct speech. The students have a good language features score. Meaning that they can identify the language characteristics in narrative text. Furthermore, 199 (88\%) students agree that narrative text uses simple past tense in its sentences. After that, 155 (68\%) students know that narrative texts often use direct speech, and they know its example. The students who know direct speech can write one example of direct speech. For the adverb of time, around 119 (52\%) students understand about adverbs of time and know its example. However, the researcher found that many students still do not know about the adverb of time. The researcher found that $108(47 \%)$ students do not know how adverbs of time are implemented, and they do not know the example of adverbs of time narrative text. This score is higher than direct speech; the students who do not know the direct speech is 72 (31\%). Adverb of time is one of the essentials language features in narrative text, and around half of the students still do not understand the adverb of time. The average percentage for language features is $70 \%$ of students consider that they do not have problem and $30 \%$ of students have language features problems. Thus, in terms of the language features, the students mostly understand the language characteristic of narrative text, but they still find difficulties identifying the adverb of time.

The fourth findings is the background knowledge problems. There four statements in the background knowledge problem. The details of the result are presented in Table 5. 
Table 5. The Students Problems in Background Knowledge

\begin{tabular}{|c|c|c|c|c|c|}
\hline No & Questions/Statements & $\begin{array}{l}\text { Strongly } \\
\text { Disagree }\end{array}$ & Disagree & Agree & $\begin{array}{c}\text { Strongly } \\
\text { Agree }\end{array}$ \\
\hline 1 & $\begin{array}{l}\text { I can relate with any } \\
\text { knowledge that I have when I } \\
\text { read a narrative text }\end{array}$ & $\begin{array}{c}8 \\
(3.5 \%)\end{array}$ & $\begin{array}{c}78 \\
(34.3 \%)\end{array}$ & $\begin{array}{c}116 \\
(51.1 \%)\end{array}$ & $\begin{array}{c}25 \\
(11 \%)\end{array}$ \\
\hline 2 & $\begin{array}{l}\text { I have the prior experience in } \\
\text { English such as grammar, } \\
\text { vocabulary that needed for } \\
\text { narrative text }\end{array}$ & $\begin{array}{c}16 \\
(7 \%)\end{array}$ & $\begin{array}{c}149 \\
(65.6 \%)\end{array}$ & $\begin{array}{c}52 \\
(23 \%)\end{array}$ & $\begin{array}{c}10 \\
(4.4 \%)\end{array}$ \\
\hline 3 & $\begin{array}{l}\text { Its easy for me to connect } \\
\text { ideas between words }\end{array}$ & $\begin{array}{c}11 \\
(4.8 \%)\end{array}$ & $\begin{array}{c}107 \\
(40 \%)\end{array}$ & $\begin{array}{c}91 \\
(40 \%)\end{array}$ & $\begin{array}{c}18 \\
(8 \%)\end{array}$ \\
\hline 4 & $\begin{array}{l}\text { When I'm struggling with } \\
\text { connecting ideas, sometimes I } \\
\text { look in the previous sentence } \\
\text { and guess the meaning from it. }\end{array}$ & $\begin{array}{c}3 \\
(1.3 \%)\end{array}$ & $\begin{array}{c}21 \\
(9.2 \%)\end{array}$ & $\begin{array}{c}164 \\
(72.2 \%)\end{array}$ & $\begin{array}{c}39 \\
(17.2 \%)\end{array}$ \\
\hline & Average Results & $6.1 \%$ & $37.2 \%$ & $46.5 \%$ & $10.2 \%$ \\
\hline & Total & \multicolumn{2}{|c|}{$43.3 \%$} & \multicolumn{2}{|c|}{$56.7 \%$} \\
\hline
\end{tabular}

The first result on table 5 is that $141(62 \%)$ students agree that they can recall their previous English experience when reading narrative text. Their previous experiences are in grammar, vocabulary, stories, and language features. This background knowledge is helpful for students to comprehend the narrative text. Even though the students can recall their previous experience, The $165(72.6 \%)$ students state that they did not have many vocabulary and grammar experience before. This result proves that the students have a lack of vocabulary banks and grammar skills. Then, 118 (52\%) of the students states that they have difficulty in connecting ideas between words. However, when they have difficulty connecting ideas, 203 $(89.4 \%)$ students agree that they can overcome it by looking at the previous sentence and guessing the meaning from it. The average percentage for background knowledge is $43.2 \%$ have the difficulty in the background knowledge aspect and $56.7 \%$ do not have the difficulty in the background knowledge.

The fifth finding is grammar problem. There are six statements about students' problems in grammar. The details of the result are presented in Table 6 .

Table 6. The Students Problems in Grammar

\begin{tabular}{|c|c|c|c|c|c|}
\hline No & Questions/Statements & $\begin{array}{l}\text { Strongly } \\
\text { Disagree }\end{array}$ & Disagree & Agree & $\begin{array}{l}\text { Strongly } \\
\text { Agree }\end{array}$ \\
\hline 1 & $\begin{array}{l}\text { I am aware of the tense used } \\
\text { in narrative text }\end{array}$ & $\begin{array}{c}13 \\
(5.7 \%) \\
\end{array}$ & $\begin{array}{c}57 \\
(25.1 \%) \\
\end{array}$ & $\begin{array}{c}135 \\
(59.4 \%) \\
\end{array}$ & $\begin{array}{c}22 \\
(9.6 \%) \\
\end{array}$ \\
\hline 2 & $\begin{array}{l}\text { I know that a narrative text } \\
\text { often use the simple past } \\
\text { tense }\end{array}$ & $\begin{array}{c}4 \\
(1.7 \%)\end{array}$ & $\begin{array}{c}23 \\
(10.1 \%)\end{array}$ & $\begin{array}{c}160 \\
(70.5 \%)\end{array}$ & $\begin{array}{c}40 \\
(17.6 \%)\end{array}$ \\
\hline 3 & $\begin{array}{l}\text { I have already understand the } \\
\text { simple past tense }\end{array}$ & $\begin{array}{c}19 \\
(8.3 \%) \\
\end{array}$ & $\begin{array}{c}127 \\
(56 \%)\end{array}$ & $\begin{array}{c}64 \\
(28.2 \%) \\
\end{array}$ & $\begin{array}{c}17 \\
(7.5 \%) \\
\end{array}$ \\
\hline 4 & $\begin{array}{l}\text { I know the formula that made } \\
\text { up the simple past tense }\end{array}$ & $\begin{array}{c}8 \\
(3.5 \%)\end{array}$ & $\begin{array}{c}46 \\
(20.2 \%) \\
\end{array}$ & $\begin{array}{c}138 \\
(60.8 \%)\end{array}$ & $\begin{array}{c}35 \\
(15.4 \%)\end{array}$ \\
\hline 5 & $\begin{array}{l}\text { I am familiar with the second } \\
\text { form of most verbs }\end{array}$ & $\begin{array}{c}9 \\
(4 \%)\end{array}$ & $\begin{array}{c}42 \\
(18.5 \%)\end{array}$ & $\begin{array}{c}150 \\
(66 \%)\end{array}$ & $\begin{array}{c}26 \\
(11.4 \%)\end{array}$ \\
\hline 6 & $\begin{array}{l}\text { I am familiar with the example } \\
\text { of simple past tense }\end{array}$ & $\begin{array}{c}4 \\
(1.7 \%)\end{array}$ & $\begin{array}{c}33 \\
(14.5 \%) \\
\end{array}$ & $\begin{array}{c}128 \\
(56.3 \%)\end{array}$ & $\begin{array}{c}62 \\
(27.3 \%)\end{array}$ \\
\hline
\end{tabular}




\begin{tabular}{lccccc}
\hline No & Questions/Statements & $\begin{array}{l}\text { Strongly } \\
\text { Disagree }\end{array}$ & Disagree & Agree & $\begin{array}{c}\text { Strongly } \\
\text { Agree }\end{array}$ \\
\hline Average Results & $4.4 \%$ & $24 \%$ & $56.8 \%$ & $14.8 \%$ \\
\hline Total & \multicolumn{2}{c}{$28.4 \%$} & \multicolumn{2}{c}{$71.6 \%$} \\
\hline
\end{tabular}

The first result shows that 157 (69\%) students are aware of the tenses used in narrative text. Next, the $200(88 \%)$ students agree that narrative text often uses simple past tense on the sentences, and 173 (76\%) of them know the formula that made up the simple past tense. Those students can also write the formula of a simple past tense sentence. And then 176 (77.4\%) students know the second form of most verbs. Those students can write five examples of the second form of the verbs. Also, 190 (83.6\%) students are familiar with the example of simple past tense sentences. Even though most of the students are familiar with the grammar especially simple past tense, $146(64.3 \%)$ of them acknowledge that they still do not understand the simple past tense. Therefore, the students need more exercise and training on the grammar aspect, especially in the simple past tense. For the average grammar percentage, $28.2 \%$ of the students have problem in grammar and $71.6 \%$ of students do not have problem in grammar. All in all, the students are already understand the basic grammar in the narrative text.

The last finding is the overall score. Table 7 shows the details of the result.

Table 7. The students' overall score

\begin{tabular}{llcccc}
\hline No & $\begin{array}{c}\text { Comprehension } \\
\text { Problems }\end{array}$ & $\begin{array}{c}\text { Strongly } \\
\text { Disagree }\end{array}$ & Disagree & Agree & $\begin{array}{c}\text { Strongly } \\
\text { Agree }\end{array}$ \\
\hline 1 & Vocabulary & $7.3 \%$ & $44.7 \%$ & $35.5 \%$ & $12.5 \%$ \\
\hline 2 & Text Structure & $3 \%$ & $14 \%$ & $68.9 \%$ & $14.1 \%$ \\
\hline 3 & Language Features & $3 \%$ & $27 \%$ & $54 \%$ & $16 \%$ \\
\hline 4 & $\begin{array}{l}\text { Background } \\
\text { knowledge }\end{array}$ & $6.1 \%$ & $37.2 \%$ & $46.5 \%$ & $10.2 \%$ \\
\hline 5 & Grammar & $4.4 \%$ & $24 \%$ & $56.8 \%$ & $14.8 \%$ \\
\hline & Overall Scores & \multicolumn{2}{c}{$34.14 \%$} & \multicolumn{2}{c}{$65.86 \%$} \\
\hline
\end{tabular}

The overall scores for the students' reading comprehension are around $34 \%$ of the students have reading comprehension problems and $65.8 \%$ do not have reading comprehension problems.

\subsection{Discussion}

Based on the findings above, the senior high school students in Ponorogo have a high percentage of problems in vocabulary and background knowledge. There are $52.3 \%$ of the students have a vocabulary problem and $43.2 \%$ of students have background knowledge problem. In this research, the findings on the background knowledge and the vocabulary problems are similar to the previous research result from Sari et al. (2020), which shows that the tenth-grade students of SMA 2 Jember have difficulty on the background knowledge and vocabularies.

There is a 6-month time gap between the survey schedule and the narrative text material schedule for senior high school. According to the 2013 Curriculum, senior high school students start to learn narrative text in the first semester of the tenth grade. Then, they also learned 
narrative text in the second semester of the ninth grade in Junior High School. It means that senior high school students already learn narrative text twice. However, the researcher conducted the research six months after they learned the narrative text. Although the students have learned narrative text twice, they might have forgotten what they learned. Hence, the senior high school students in Ponorogo still have problems in vocabulary and background knowledge.

The senior high school students in Ponorogo still lack vocabulary skills. Having limited vocabulary has been a problem for EFL students (Garcia-Castro, 2020). According to the average percentage result of vocabulary, $47.8 \%$ of students do not have the vocabulary problems and $52.1 \%$ of students have the vocabulary problems. However, In this research, $69.5 \%$ of the students overcome difficult vocabulary by elaborating them with the previous sentence. That is one of the ways for students to overcome difficult vocabulary. There are many ways for students to improve their vocabulary skills, such as word games, watching English videos, and listening to songs. Therefore, it is essential to keep students with vocabulary exercises that will help them master vocabulary skills. Reading influences the students' vocabulary development. If the students; vocabulary is low, it means that they tend to read less (Cain \& Oakhill, 2011). The result on students' vocabulary is similar to Davoudi and Yousefi's research (2017), which states that vocabulary knowledge is one of the problem in the EFL students. This finding is also similar to the previous research result from Sari et al. (2020), which shows that the tenth-grade students of SMA 2 Jember have difficulty in vocabulary. According to Jayanti (2016), EFL students still have difficult vocaularies in reading English text.

The text structure is also essential for students to master because it will help the students comprehend the narrative text better. The senior high school students in Ponorogo got a good result on the text structure. In this research, $83 \%$ of the students do not have the text structure problem and $16.8 \%$ of the students state that they have text structure problem. Those students are also able to write all the text structure of a narrative text. Also, they can write one of the functions of the text structure of a narrative text. The students can also write one of the text structure in narrative text and describe its function. This is result is in contrast with the previous research results. According to Dahliana (2016), although Indonesian students already learned English, most of them still does not understand various English text. Only the research from Khoirunnisa (2019) shows the Junior High school students have the text structure problems. In addition, Usman (2018) state that most Indonesian students does not understand the English text they read. However, the result shows that the senior high school students in Ponorogo have no problem with the text structure aspect. It means that the senior high school students in Ponorogo have improved their narrative text knowledge.

The next aspect is the language features. There are many language features in narrative text, such as tenses, adverbs of time, and direct speech. The students have a good language features score. Meaning that they can identify the language charateristic in narrative text. In this research, around $70 \%$ of the students do not have the language features problem in a narrative and $30 \%$ of students states that they have the language features problem. Then, the $88 \%$ of the students agree that narrative text uses simple past tense in its sentences. After that, $68 \%$ of the students know that a narrative text often uses direct speech and $52 \%$ of the students understand the adverb of time in narrative text. Moreover, most of the students who do not have the language features problem can write an example of adverb of time and an example of direct speech usage. All in all, there is no significant problem in the language 
features aspect. Most of the students already understand the language features in narrative text.

The next is aspect to discuss is background knowledge. Background knowledge help students to make reasonable inferences of the text they read (Elbro \& Iversen, 2013). In this survey background knowledge is still not quite familiar for students whereas background knowledge is important in reading narrative text. It is important because it prepares the students to comprehend the text. Background knowledge is mostly about vocabularies, related reading experiences, and ideas in the past. Recalling the background knowledge is not always easy. Zuhra (2015) state that Indonesian students does not have sufficient knowledge in order comprehend an English text. It depends on the readers' experience. In this research, the average score for background knowledge is $56.7 \%$ students state that they do not have the background knowledge problem, and $43.2 \%$ states that they have the background knowledge problem It means that only $56.7 \%$ of the students can recall their background knowledge. These findings are consistent with the previous research result from Sari et al. (2020), which shows that the tenth-grade students of SMA 2 Jember have difficulty in background knowledge. Since the students already develop a good reading habit in reading Indonesian stories, the teacher should provide more English reading materials to increase their background knowledge.

The last aspect to discuss is grammar. The aspect that influence the students' reading comprehension skills is not just vocabulary or background knowledge but also grammar skill (Shanahan, 2013). The focus of the grammar in this study is the usage of tenses in narrative text. Most of the students already understand the grammar in narrative text. For the average percentage, around $71.6 \%$ do not have problem in grammar and $28.2 \%$ of students have grammar problem. However, $64.3 \%$ of the students said that they have little experience in grammar. Therefore, students need more grammar exercises. The students need exercises like changing the sentence types, for example, changing a positive sentence into a negative sentence, a positive sentence into a question, and many more possibilities. Furthermore, the teacher might highlight examples of sentences in the narrative text to give more insight to the students. These findings are similar to the research from Davoudi and Yousefi (2017) which states that there are many reading comprehension problems in EFL classrooms, such as deficits in vocabulary knowledge, background knowledge, and problems with grammatical knowledge. The senior high school students in Ponorogo have enough grammar knowledge but need more exercises to enhance their grammar skills.

\section{Conclusion}

The findings and discussion in the previous chapter explained that most of the senior high school students in Ponorogo have problems with vocabulary and background knowledge. Then, the time gap between the time of the research and the schedule for the narrative text material is far. So the students might have forgotten some of the background knowledge and vocabulary of a narrative text. Also, the similarity from the previous research result implied that the students have not improved in vocabulary and background knowledge.

Vocabulary and background knowledge is still a problem for students in this study. The students can improve their vocabulary mastery by reading more narrative text or other any other English text. The teacher can use narrative text, or other interesting story as the reading material. Then, the teacher can also improve the background knowledge by providing the 
students with the picture books. Picture books can increase the student's participation and memory about the story in the picture books.

The researcher suggested that teachers use this research result to increase their awareness of the students' problem when reading narrative text. Second, the teachers can improve the students' reading comprehension skills especially vocabulary and background knowledge. One of the ways to improve the vocabulary and background knowledge is by giving the students interesting reading material and encourage them to read more. The teacher can use narrative text, picture books, or comic books to motivate the students to read. When the students read more, they can develop their vocabulary lists and enhance their background knowledge.

It has to be noted that this research still has limitation. First, since the data from the survey is lack of detailed information, it is better for the future research to use the vocabulary test to get more detailed information about the students' vocabulary problems. Future research could also use concept maps to test the students' background knowledge on narrative text. Second, the researcher recommend conducting the future research close to the students' narrative text material schedule to keep the students have a fresh memory about a narrative text.

Lastly, the researcher hoped that the Indonesian students can have better reading comprehension skills and achieve better reading score in the next PISA survey or other international surveys. The researcher also hoped for the teacher to take this research results into consideration when they want to improve the students reading comprehension skills.

\section{References}

Amalia, R. (2017). Teaching reading comprehension in narrative by using character map strategy to the eight grade students of SMP Azzawiyah Tanjung Batu. Jurnal Pendidikan dan Pengajaran, 4(1), 24-39. Retrieved from http://jurnal.radenfatah.ac.id/index.php/edukasi/article/view/1525

Andini, Y., Hadriana, \& Delfi, S. (2017). The correlation between grammar mastery and reading comprehension of the second grade students of SMPN 12 Pekanbaru. Jurnal Online Mahasiswa Fakultas Keguruan Dan Ilmu Pendidikan Universitas Riau, 4(1), 1-10. Retrieved from https://jom.unri.ac.id/index.php/JOMFKIP/article/view/13349/12913

Andri, Supardi, I., \& Suhartono, L. (2015). Teaching reading comprehension in narrative text using numbered heads together technique. Journal Pendidikan dan Pembelajaran Khatulistiwa, 4(11), 70-83. Retrieved from https://jurnal.untan.ac.id/index.php/jpdpb/article/view/12384

Cain, K., \& Oakhill, J. (2011). Matthew effects in young readers: Reading comprehension and reading experience aid vocabulary development. Journal of Learning Disabilities, 44(5), 431-443. doi: https://doi.org/10.1177/0022219411410042

Cohen, L., Manion, L., \& Morrison, K. (2007). Research methods in education (6th ed.). London, New York: Routllege Falmer.

Cordeur, M. L. (2010). The struggling reader: Identifying and addressing reading problems successfully at an early stage. A Journal of Language Learning, 26(2), 77-89. doi: https://doi.org/10.5785/26-2-23

Dahliana, S. (2016). Partnership activity in EFL reading classroom. Englisia Journal, 3(2), 83. Retrieved from https://jurnal.ar-raniry.ac.id/index.php/englisia/article/view/1022/930

Davoudi, M., \& Yousefi, D. (2015). Comprehension Breakdown: A Review of Research on EFL Learners" Reading Difficulty and Problems. International Journal of Language and Applied Linguistics, 58-72. Retrieved from http://www.khatesefid.com/journal/wp-content/uploads/2015/07/58-721.pdf 
Dymock, S. (2007). Comprehension strategy instruction: Teaching narrative text structure awareness. The Reading Teacher, 61(2), 161-167. doi: https://doi.org/10.1598/RT.61.2.6

Data Pokok Pendidikan Kementrian Pendidikan dan Kebudayaan Kabupaten Ponorogo. (2020). Dapo Kemendikbud (online). Retrieved December 1, 2020, from dapo.kemdikbud.go.id

Elbro, C., \& Buch-Iversen, I. (2013). Activation of background knowledge for inference making: Effects on reading comprehension. Scientific Studies of Reading, 17(6), 435-452. doi: https://doi.org/10.1080/10888438.2013.774005

Garcia-Castro, V. (2020). The effects of vocabulary knowledge in L2 semantic lexical engagement: The case of adult learners of English as a second language. Indonesian Journal of Applied Linguistics, 10(1), 261-270. doi: https://doi.org/10.17509/ijal.v10i1.25068

Gunning, T. G. (2002). Assessing and correcting reading and writing difficulties. Boston: Allyn \& Bacou.

Hamra, A., \& Syatriana, E. (2010). Developing a model of teaching reading comprehension. Teflin, 21(1), 2740. doi: http://dx.doi.org/10.15639/teflinjournal.v21i1/27-40

Jayanti, F. G. (2016). Reading difficulties: Comparison on students and teachers perception. Proceedings of Fourth International Seminar on English Language and Teaching, 4(1), 296-301. Retrieved from ejournal.unp.ac.id/index.php/selt/article/view/6939

Khoirunnisa, A. (2019). Students' difficulties in comprehending narrative text. Teaching of English Language and Literature Journal, 7(2), 65-74. Retrieved from http://journal.umsurabaya.ac.id/index.php/Tell/article/view/3441/pdf

Latief, M A. (2017). Research method on language learning: An introduction. Malang: Universitas Negeri Malang

Masrai, A. (2019). Vocabulary and reading comprehension revisited: Evidence for high-, mid-, and lowfrequency vocabulary knowledge. SAGE Open, 9(2). doi: https://doi.org/10.1177/2158244019845182

Nanda, D. W., \& Azmy, K. (2020). Poor reading comprehension issue in EFL classroom among Indonesian secondary school students: Scrutinizing the causes, impacts and possible solutions. Englisia: Journal of Language, Education, and Humanities, 8(1), 12 . Retrieved from https://jurnal.arraniry.ac.id/index.php/englisia/article/view/6771

Neuman, S. B., Kaefar, T., \& Pinkam, A. (2014). Building background knowledge. The Reading Teacher, 68(2), 145-148. doi: https://doi.org/10.1002/trtr.1314

OECD. (2018). PISA 2018 Results: Indonesia. Paris: OECD Publishing.

Permendikbud No 69 Tahun 2013 tentang KD dan struktur kurikulum SMA-MA. Kemendikbud (onliine), (https://www.kemdikbud.go.id/), accessed on December 1st 2021

Sari, G. R., Santihastuti, A., \& Wahjuningsih, E. (2020). Students' perception on reading comprehension problems in narrative text. LLT Journal, 23(2), 342-353. Retrieved from https:/ejournal.usd.ac.id/index.php/LLT/article/view/2211

Shanahan, T. (2013). Grammar and comprehension: Scaffolding student interpretation of complex sentences. Retrieved February 24, 2021, from www.shanahanonliteracy.com/2013/12/grammar-andcomprehensionscaffolding.html.

Smith, R., Snow, P., Serry, T., \& Hammond, L. (2021). The role of background knowledge in reading comprehension: A critical review. Reading Psychology, 42(3), 214-240. Retrieved from https://www.tandfonline.com/doi/full/10.1080/02702711.2021.1888348

Snow, C. E. (2010). Reading comprehension: Reading for learning. In P. Peterson, E. Baker, \& B. McGaw (Eds.), International encyclopedia of education, vol. 5 (pp. 413-418). Retrieved from https://www.scholars.northwestern.edu/en/publications/

Solihin, L., Utama, B., Pratiwi, I., \& Novirina. (2019). Indeks Aktivitas Literasi Membaca 34 Provinsi. Jakarta: Pusat Penelitian Kebijakan Pendidikan dan Kebudayaan, Badan Penelitian dan Pengembangan, Kementerian Pendidikan dan Kebudayaan. 
Stæhr, L. (2008). Vocabulary size and the skills of listening, reading and writing. Language Learning, 36(1), 139-152. doi: https://doi.org/10.1080/09571730802389975

Subasini, M \& Kokilavani, B. (2013). Significance of grammar in technical English. International Journal of English Literature and Culture, 1(3), 56-58. doi: 10.14662/IJELC2013.022

Usman, B., Fata, I. A., \& Pratiwi, R. (2019). Teaching reading through Know-Want-Learned (KWL) strategy: The effects and benefits. Englisia Journal, 6(1), 35. doi: https://doi.org/10.22373/ej.v6i1.3607

Zuhra. (2015). Senior high school students' difficulties in reading comprehension. English Education Journal, 6(3), 430-441. Retrieved from http://jurnal.unsyiah.ac.id/EEJ/article/view/2584 